\title{
Wpływ temperatury powietrza ciągu wstecznego na działanie urządzeń gazowych typu B
}

\begin{abstract}
W artykule przeanalizowano problem wpływu prędkości napływu powietrza oraz jego temperatury na działanie palnika inżektorowego. Zaprezentowano wyniki badań wpływu wyżej wymienionych parametrów na proces spalania gazu w palniku inżektorowym stosowanym w gazowych przepływowych ogrzewaczach wody. Sprawdzono wpływ prędkości napływu powietrza dla trzech wielkości: $0,6 \mathrm{~m} / \mathrm{s}, 0,8 \mathrm{~m} / \mathrm{s}$ oraz $1,0 \mathrm{~m} / \mathrm{s}$ oraz jego temperatury: $11^{\circ} \mathrm{C}, 17^{\circ} \mathrm{C}$ i $25^{\circ} \mathrm{C}$. Analiza uzyskanych zależności zawartości tlenku węgla(II) w spalinach od prędkości oraz temperatury napływającego powietrza pozwoliła na uzyskanie odpowiedzi na pytanie, w jaki sposób parametry te oddziałują na proces spalania, a co za tym idzie - na bezpieczeństwo użytkowania przepływowych ogrzewaczy wody.
\end{abstract}

Słowa kluczowe: ciąg wsteczny, temperatura, urządzenia typu B.

\section{Impact of reverse draft air temperature on the operation of type B gas appliances}

The article discusses the problem of the influence of the velocity of air flow and its temperature, on the effect of the injector burner. The results of studies on the influence of the above mentioned parameters, on the process of gas combustion in the injector burner used in flow water heaters, were presented. The influence for three value of air velocities were tested: $0.6 \mathrm{~m} / \mathrm{s}, 0.8 \mathrm{~m} / \mathrm{s}$ and $1.0 \mathrm{~m} / \mathrm{s}$, and temperatures of $11^{\circ} \mathrm{C}, 17^{\circ} \mathrm{C}$ and $25^{\circ} \mathrm{C}$. Analysis of the obtained dependence of the carbon monoxide(II) content in the exhaust gas from the velocity and the temperature of the incoming air, allowed to obtain an answer to the question of how these parameters affect the combustion process and thus, the safety of the use of continuous flow water heaters.

Key words: reverse draft, temperature, type B gas appliance.

\section{Wstęp}

Od września 2015 r. do 8 stycznia 2016 r. w Polsce strażacy odnotowali w sumie 1839 zdarzeń związanych z tworzeniem się tlenku węgla(II) przy użytkowaniu urządzeń gazowych [1]. Ponad tysiąc osób uległo podtruciu tą niebezpieczną substancją, a 22 osoby zmarły. Podobne sytuacje powtarzają się rokrocznie w okresie jesienno-zimowym, w którym notuje się wzmożoną liczbę interwencji wynikających z działania tlenku węgla(II) [4, 5, 9, 10]. Jak wynika z prowadzonych statystyk, rocznie dochodzi do około 3700 tego typu zdarzeń, w których poszkodowanych zostaje około 2000 osób. W ostatnich 6 latach wartości te utrzymują się na zbliżonym poziomie $[4,5,10]$. Jedynie liczba ofiar śmiertelnych spadła w tym okresie o około połowę, jednak nadal odnotowuje się rocznie około 50 śmiertelnych zatruć tlen- kiem węgla(II). Szczegółowa analiza danych policyjnych oraz informacji z rejestrów zakładów medycyny sądowej wyraźnie pokazuje, że około $85 \div 90 \%$ wypadków śmiertelnych spowodowanych zatruciami tlenkiem węgla(II) zdarza się w okresie od października do kwietnia [11, 13]. O tym, jak istotnym problemem są śmiertelne zatrucia tlenkiem węgla(II), świadczy fakt, że rocznie z tego powodu ginie jedna osoba na każde 100000 użytkowników gazowych przepływowych grzejników wody [12]. Jeśli statystyki śmiertelnych zatruć tlenkiem węgla(II) zestawi się ze średnimi wartościami temperatury powietrza, wówczas można zauważyć, że więcej zatruć śmiertelnych występuje jesienią niż zimą i wczesną wiosną. Nawet przy zbliżonych średnich temperaturach powietrza, wynoszących około $7,5^{\circ} \mathrm{C}$, w październiku 
odnotowuje się o $40 \%$ więcej śmiertelnych zatruć niż w kwietniu [12].

Jedną z głównych przyczyn zatruć tlenkiem węgla(II) jest powstawanie ciągu wstecznego. Ciąg wsteczny to zjawisko wynikające z różnicy gęstości powietrza spowodowanej wahaniami temperatury i ciśnienia. Temperatura powietrza, szczególnie w okresie zimowym, na początku kanału spalinowego (czyli w mieszkaniu) i na jego końcu (czyli w okolicach wylotu na szczycie budynku) jest różna. W związku z tym może dochodzić do napływu zimnego powietrza do mieszkania poprzez kanały spalinowe lub wentylacyjne. Dzieje się tak zwłaszcza wtedy, gdy urządzenie typu B od dłuższego czasu nie było używane $[6,7,8]$. Jednym z następstw ciągu wstecznego jest za- wracanie spalin do palnika inżektorowego, powodujące zwiększenie zawartości tlenku węgla(II) w spalinach. W takiej sytuacji spaliny wydostają się z urządzenia poniżej palnika, dostając się do pomieszczenia, w którym znajduje się urządzenie. W niniejszym artykule opisano, jaki wpływ ma temperatura oraz prędkość powietrza napływającego na działanie pojedynczego elementu stosowanego w typowych palnikach inżektorowych zamontowanych w urządzeniach z otwartą komorą spalania. Przeprowadzone i opisane w niniejszym artykule badania mają na celu zobrazowanie, jak duży wpływ na prawidłową pracę urządzeń typu B mają warunki środowiska, w jakich pracuje urządzenie, oraz jakie zagrożenie dla użytkowników może stwarzać powstawanie ciągu wstecznego.

\section{Metodyka badań}

W celu przeprowadzenia odpowiednich badań przygotowane zostało stanowisko badań do symulowania różnych warunków pracy palnika inżektorowego. Stanowisko pomiarowe składało się z tunelu pomiarowego, w którym został umieszczony element palnika inżektorowego, oraz systemu chłodzenia powietrza napływającego do wyżej wymienionego elementu. Badania wpływu temperatury powietrza na pracę palnika inżektorowego wykonano w 9 seriach pomiarowych (tablica 1). Poszczególne serie różniły się prędkością napływu powietrza i/lub temperaturą powietrza napływającego do badanego elementu.

Tablica 1. Warunki prowadzenia badań w poszczególnych seriach pomiarowych

\begin{tabular}{|c|c|c|}
\hline $\begin{array}{c}\text { Oznaczenie } \\
\text { serii }\end{array}$ & $\begin{array}{c}\text { Prędkość napływu } \\
\text { powietrza } \\
{[\mathrm{m} / \mathrm{s}]}\end{array}$ & $\begin{array}{c}\text { Temperatura } \\
\text { napływającego powietrza } \\
{\left[{ }^{\circ} \mathrm{C}\right]}\end{array}$ \\
\hline S1 & 1,0 & 25,0 \\
\hline S2 & 0,8 & 25,0 \\
\hline S3 & 0,6 & 25,0 \\
\hline S4 & 1,0 & 17,0 \\
\hline S5 & 0,8 & 17,0 \\
\hline S6 & 0,6 & 17,0 \\
\hline S7 & 1,0 & 11,0 \\
\hline S8 & 0,8 & 11,0 \\
\hline S9 & 0,6 & 11,0 \\
\hline
\end{tabular}

Dla każdej z serii pomiarowych przeprowadzono 6 niezależnych pomiarów, realizowanych w ciągu dwóch dni (po trzy w każdym dniu). Istotne jest to, że po wykonaniu każdego pomiaru następowała przerwa w celu obniżenia temperatury układu badawczego do temperatury pokojowej. W badaniach uwzględniono trzy różne prędkości napływu powietrza, w zakresie od 0,6 do $1,0 \mathrm{~m} / \mathrm{s}$. Nastawa zadanej prędkości przepływu powietrza była realizowana za pomoca sterownika wentylatora kanałowego, natomiast prędkość napływającego powietrza była kontrolowana anemometrem. Wartości napływu powietrza wyższe niż $1,0 \mathrm{~m} / \mathrm{s}$ nie zostały wzięte pod uwagę, gdyż powodowały brak możliwości trwałego zapalenia badanego palnika. W trakcie badań nie uwzględniono również napływów powietrza o prędkości poniżej $0,6 \mathrm{~m} / \mathrm{s}$, gdyż w takich warunkach palnik pracował normalnie i spaliny nie dostawały się do strefy podpalnikowej. Oznacza to, że w przypadku badanego elementu powietrze napływające z prędkością mniejszą niż $0,6 \mathrm{~m} / \mathrm{s}$ nie powoduje niekorzystnego działania związanego z wydostawaniem się spalin ze strefy podpalnikowej. Po ustawieniu żądanej wartości napływu powietrza regulowano jego temperaturę. Regulacja temperatury następowała poprzez zastosowanie trójnika z przesłoną - za jego pomocą regulowano stosunek powietrza zaczerpniętego z układu chłodzącego do powietrza pobranego $\mathrm{z}$ otoczenia $\mathrm{w}$ celu uzyskania stabilnej temperatury. W badaniach uwzględniono trzy wartości temperatury z zakresu od $11^{\circ} \mathrm{C}$ do $25^{\circ} \mathrm{C}$. Temperatura $25^{\circ} \mathrm{C}$, będąca najwyższą spodziewaną w okresie jesieni i wczesnej wiosny, stanowiła temperaturę otoczenia $\mathrm{w}$ momencie prowadzenia badań. W trakcie badań została ona obniżona w dwóch krokach do wartości $11^{\circ} \mathrm{C}$, która stanowi najniższą możliwą do stabilnego uzyskania na stanowisku pomiarowym. Temperaturę napływającego powietrza kontrolowano za pomocą miernika temperatury Testo 735. Po uzyskaniu założonej temperatury oraz prędkości napływającego powietrza i ich sprawdzeniu następowało włączenie piezozapalacza oraz otwarcie dopływu gazu do urządzenia. Od tego momentu następowała rejestracja wskazań analizatora w zakresie jakości spalin wydostających się poniżej badanego elementu. 
Pojedynczy pomiar jakości spalin trwał przeważnie od 3 do 5 minut i obejmował pomiar zawartości tlenu oraz tlenków węgla w spalinach. Dzięki zastosowanemu analizatorowi spalin Horiba VA-3000 możliwa była rejestracja badanych parametrów z częstotliwością 1 pomiaru co 2 sekundy. Czas prowadzenia pomiarów został dobrany w taki sposób, aby uzyskać stabilizację wyników zawartości tlenku węgla(II) w spalinach dla każdej z serii pomiarowych.

\section{Wyniki badań}

Z punktu widzenia bezpieczeństwa osób użytkujących gazowe urządzenia $\mathrm{z}$ otwartą komorą spalania najistotniejszym parametrem charakteryzującym jakość zachodzącego procesu spalania jest skład spalin [2]. Z tego względu podczas prowadzonych badań dokonywano ciągłego pomiaru składu spalin. Pomiar jakości spalin uwzględniał trzy parametry, takie jak zawartość tlenu, tlenku węgla(II) oraz tlenku węgla(IV). Należy pamiętać jednak o tym, że z wymienionych parametrów najbardziej istotnym z punktu widzenia bezpieczeństwa użytkowania urządzeń gazowych jest zawartość tlenku węgla(II). Dlatego też podczas analizy otrzymanych wyników skoncentrowano się głównie na tym parametrze. Prezentując wyniki pomiarów, posłużono się zawartościami tlenku węgla(II) przeliczonymi na suche nierozcieńczone spaliny (według wzoru 1).

$$
\mathrm{CO}_{\mathrm{p}}=\mathrm{CO}_{\mathrm{m}} \cdot \frac{21}{21-\mathrm{O}_{2}}
$$

gdzie:

$\mathrm{CO}_{\mathrm{p}}$ - zawartość tlenku węgla(II) w suchych nierozcieńczonych spalinach w ppm,

$\mathrm{CO}_{\mathrm{m}}-$ zmierzona zawartość tlenku węgla(II) w ppm,

$\mathrm{O}_{2} \quad$ - zmierzona zawartość tlenu [\%].

Taki sposób prezentacji rezultatów wynika z normy odniesienia dla urządzeń gazowych typu $\mathrm{B}_{11}$ PN-EN 15502-2-2:2014-12 Gazowe kotly centralnego ogrzewania - Część 2-2: Norma szczególowa dla urządzeń typu B1 [14]. Prowadzenie analizy przeliczonych zawartości tlenku węgla(II) ułatwia również porównanie wyników otrzymanych w różnych warunkach.

Zgodnie z przyjętą metodyką badań dla każdej serii pomiarowej wykonano 6 niezależnych pomiarów przy określonej prędkości napływu oraz temperaturze powietrza. W każdej serii pomiary oznaczone numerami od 1 do 3 zostały wykonane w ciągu jednego dnia, zaś pomiary o numerach od 4 do 6 przeprowadzono dzień później. Zabieg ten miał na celu sprawdzenie, czy możliwe jest uzyskanie powtarzalnych wyników pomiarów w warunkach zdefiniowanych dla danej serii pomiarowej. Wyniki otrzymane w przykładowej serii pomiarowej przedstawiono na rysunkach 1 i 2 . Na rysunkach tych zaprezentowano wyniki pochodzące z serii pomiarowej S2, w której temperatura napływającego powietrza wynosiła $25^{\circ} \mathrm{C}$, natomiast jego prędkość $0,8 \mathrm{~m} / \mathrm{s}$.

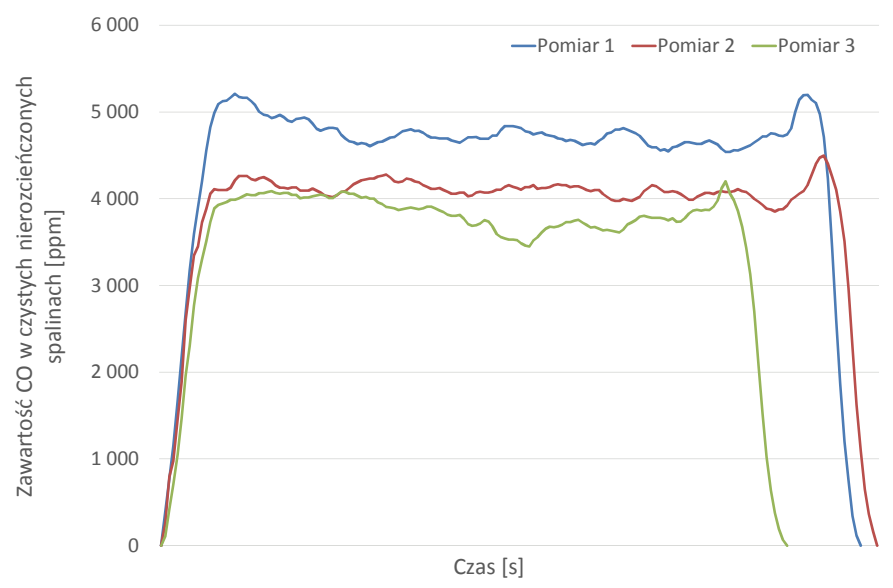

Rys. 1. Zawartość tlenku węgla(II) w suchych nierozcieńczonych spalinach uzyskana w serii S2 - pierwszy dzień pomiarowy

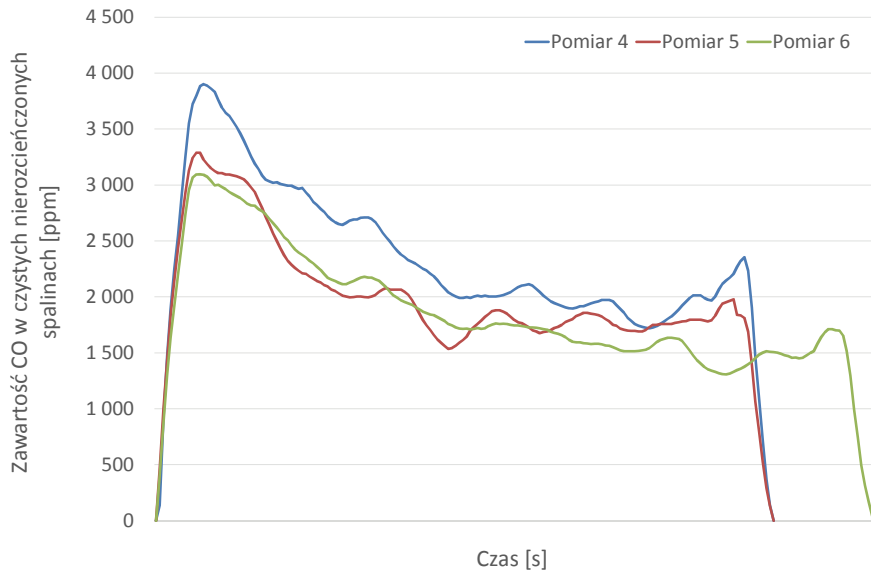

Rys. 2. Zawartość tlenku węgla(II) w suchych nierozcieńczonych spalinach uzyskana w serii S2 - drugi dzień pomiarowy

Biorąc pod uwagę wyniki uzyskane w serii S2, wyraźnie widać, że pomiary zawartości tlenku węgla(II) w spalinach otrzymane w ciągu pierwszego dnia pomiarowego stabilizują się pomiędzy 30. a 290. sekundą i w tym przedziale uzyskują wartość pomiędzy 3500 a 5000 ppm. Natomiast w przypadku drugiego dnia pomiarowego brak jest wyraźnej stabilizacji zawartości tlenku węgla(II) w spalinach, a otrzymane w poszczególnych pomiarach wartości maksymalne mieszczą się w przedziale od 3095 ppm (dla pomiaru 6) do 3902 ppm (dla pomiaru 4). Wyniki badań uzyskane w pozostałych 8 seriach pomiarowych potwierdziły tendencje wyższych zawartości tlenku węgla(II) dla trzech pierwszych 
pomiarów w stosunku do pomiarów $4 \div 6$. Zróżnicowanie wyników pomiarów prowadzonych $\mathrm{w}$ dwóch różnych dniach pomiarowych wskazywać może na fakt, że na działanie palnika inżektorowego pod wpływem ciągu wstecznego istotny wpływ (obok temperatury i prędkości napływu powietrza) mogą mieć również takie czynniki jak ciśnienie atmosferyczne oraz wilgotność powietrza. W przypadku analizy wpływu temperatury oraz prędkości napływającego powietrza na działanie palnika inżektorowego istotniejsze niż różnice uzyskiwane w pomiarach wykonanych w trakcie jednej serii pomiarowej są różnice w wynikach pomiędzy poszczególnymi seriami.

W celu dokonania oceny oddziaływania prędkości napływającego powietrza na proces spalania zachodzący w pojedynczym elemencie palnika inżektorowego przeanalizowano zależność maksymalnej oraz średniej zawartości tlenku węgla(II) od prędkości napływającego powietrza. Zależności te, z uwzględnieniem różnych temperatur napływającego powietrza, przedstawiono na rysunkach 3 i 4 .

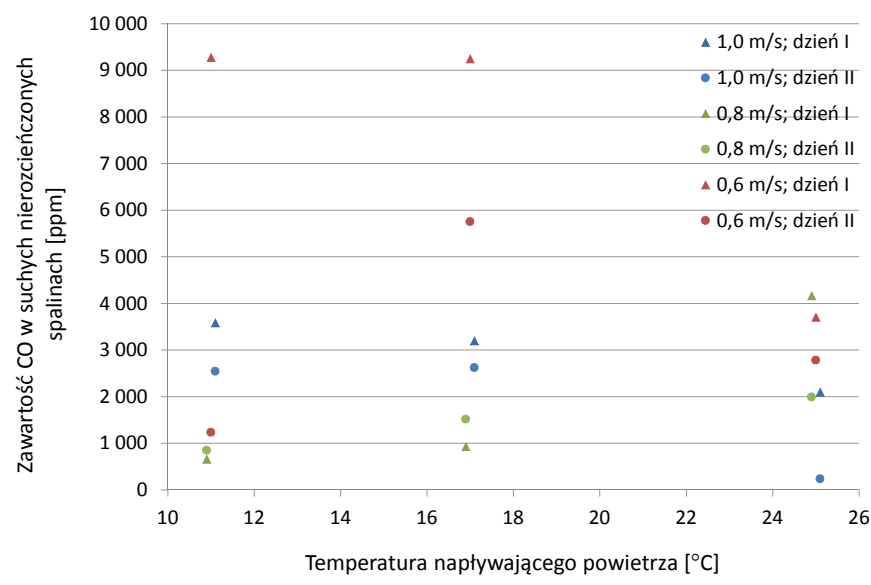

Rys. 3. Zależność maksymalnych zmierzonych zawartości tlenku węgla(II) od prędkości napływającego powietrza

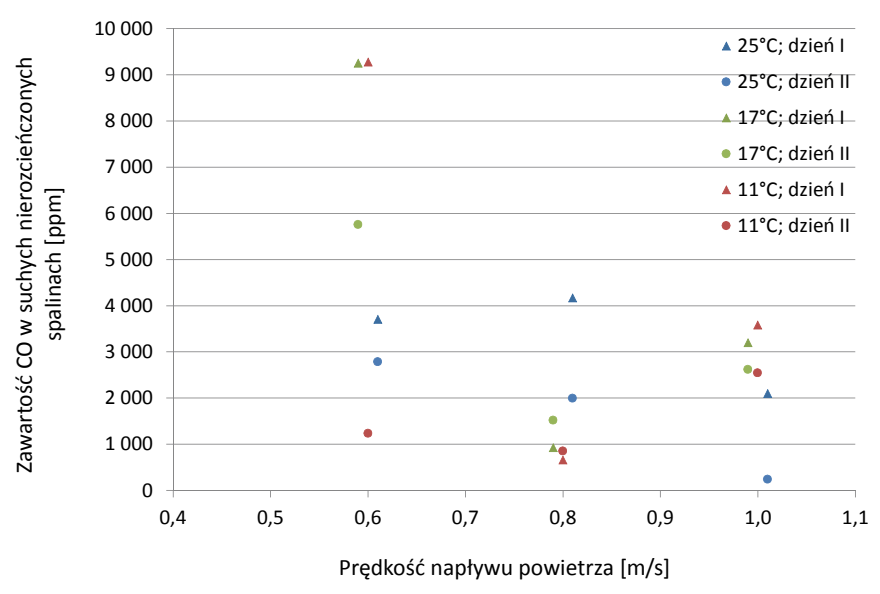

Rys. 4. Zależność średnich zmierzonych zawartości tlenku węgla(II) od prędkości napływającego powietrza

Analiza danych przedstawionych na rysunkach 3 i 4 pokazuje, że w przypadku najmniejszej rozważanej prędko- ści napływu powietrza, równej $0,6 \mathrm{~m} / \mathrm{s}$, uzyskano najbardziej zróżnicowane zawartości tlenku węgla(II) w spalinach. Duże zróżnicowanie dla tej prędkości wynika nie tylko ze zmiany temperatury powietrza napływającego na badany element. Świadczy o tym fakt, że dla najniższej rozpatrywanej temperatury pierwszego dnia badań otrzymano najwyższe zawartości tlenku(II) w spalinach, natomiast drugiego dnia wartości te były najniższe z wszystkich zmierzonych przy tej prędkości. Prędkość napływu powietrza równa $0,6 \mathrm{~m} / \mathrm{s}$ była jedyną $\mathrm{z}$ analizowanych prędkości, dla której uzyskano średnie zawartości tlenku węgla(II) przekraczające $0,5 \%$. Dodatkowo średnia zawartość tlenku węgla(II) otrzymana we wszystkich pomiarach wykonanych dla tej prędkości była bardzo wysoka i wyniosła 5332 ppm. W przypadku prędkości napływu powietrza równej $0,8 \mathrm{~m} / \mathrm{s}$ zróżnicowanie wyników pomiarów zawartości tlenku węgla(II) w spalinach jest znacznie mniejsze. Maksymalne otrzymane dla tej prędkości zawartości tlenku węgla(II) mieściły się w przedziale od 2255 do 5209 ppm, a wartości średnie wynosiły od 658 do 4164 ppm. Natomiast średnia zawartość tlenku węgla(II) w spalinach wyliczona dla tej prędkości napływu powietrza jest znacznie mniejsza niż w przypadku pomiarów przeprowadzonych dla prędkości $0,6 \mathrm{~m} / \mathrm{s}$ i wynosi 1684 ppm. Dodatkowo analiza wyników otrzymanych dla prędkości $0,8 \mathrm{~m} / \mathrm{s}$ wskazuje, że wraz ze wzrostem temperatury napływającego powietrza rośnie zmierzona zawartość tlenku węgla(II) w spalinach. Najwyższa z analizowanych prędkości napływu powietrza na pojedynczy element palnika inżektorowego wynosiła $1,0 \mathrm{~m} / \mathrm{s}$. W przypadku tej prędkości można zauważyć stosunkowo nieduże zróżnicowanie uzyskanych wyników pomiarów tlenku węgla(II) w spalinach. Maksymalne zawartości tego związku mieściły się w przedziale od 3301 do 12864 ppm, natomiast wartości średnie wahały się od 1232 do 9275 ppm. Średnia zawartość tlenku węgla(II) w spalinach dla tej prędkości wynosiła 2379 ppm i była wyższa od wartości uzyskanej dla prędkości $0,8 \mathrm{~m} / \mathrm{s}$ o $695 \mathrm{ppm}$, a niższa od średniej wartości uzyskanej dla prędkości $0,6 \mathrm{~m} / \mathrm{s}$ - o $2953 \mathrm{ppm}$. Analiza wyników pomiarów prowadzonych przy prędkości napływającego powietrza równej $1,0 \mathrm{~m} / \mathrm{s}$ pokazała również, że - odwrotnie niż w przypadku pomiarów dla prędkości $0,8 \mathrm{~m} / \mathrm{s}$ - wraz ze wzrostem temperatury napływającego powietrza maleje średnia zawartość tlenku węgla(II) w spalinach.

Wyniki badań można przedstawić również w układzie obrazującym zależność zawartości tlenku węgla(II) w spalinach od temperatury napływającego powietrza (rysunki 5 i 6 ). Taki sposób prezentacji pozwala na przeprowadzenie oceny wpływu temperatury powietrza na proces spalania gazu.

Analiza danych przedstawionych na rysunkach 5 i 6 pozwala stwierdzić, że spadek temperatury powietrza na- 


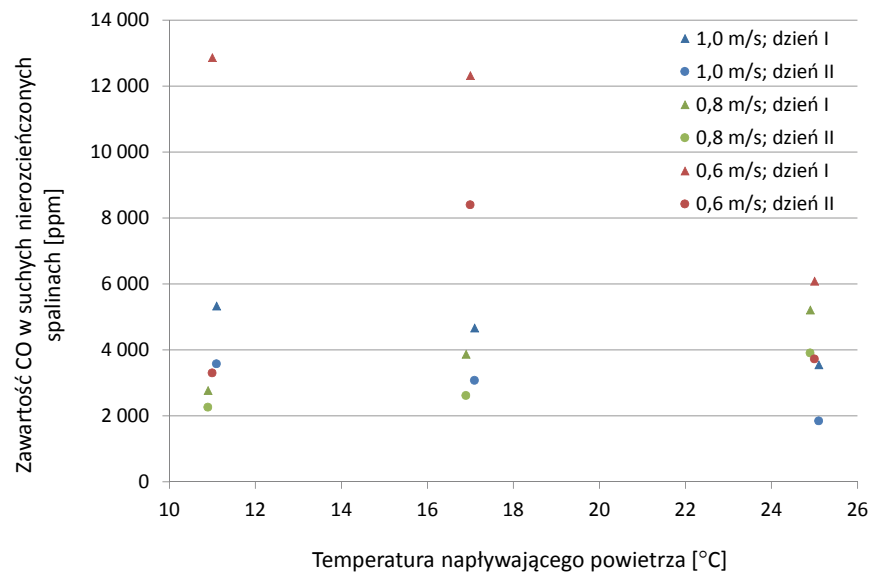

Rys. 5. Zależność maksymalnych zmierzonych zawartości tlenku węgla(II) od temperatury napływającego powietrza

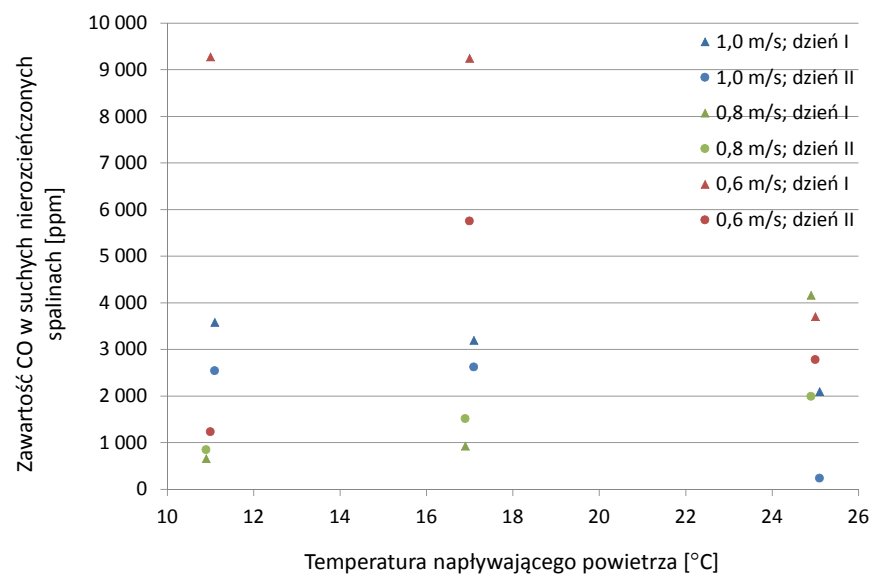

Rys. 6. Zależność średnich zmierzonych zawartości tlenku węgla(II) od temperatury napływającego powietrza

pływającego na pojedynczy element palnika inżektorowego powoduje zwiększenie rozrzutu pomiędzy uzyskanymi wynikami zarówno pierwszego, jak i drugiego dnia pomiarowego. Zmiany temperatury napływającego powietrza przy jednoczesnym zachowaniu jego stałej prędkości powodują zmiany zawartości tlenku węgla(II) w spalinach. Kierunek tych zmian jest trudny do przewidzenia i nie wykazuje korelacji (dodatniej bądź ujemnej) z temperaturą napływającego powietrza. Świadczy o tym fakt, że dla prędkości napływu równej $1,0 \mathrm{~m} / \mathrm{s}$ wraz ze spadkiem temperatury napływającego powietrza rośnie średnia zawartość tlenku węgla(II) w spalinach, natomiast w przypadku napływu powietrza o prędkości $0,8 \mathrm{~m} / \mathrm{s}$ zaobserwować można odwrotną zależność, czyli spadek średniej zawartości tlenku węgla(II) w spalinach wraz ze spadkiem temperatury napływającego powietrza. Jeszcze inaczej przedstawia się sytuacja w przypadku prędkości napływu powietrza równej $0,6 \mathrm{~m} / \mathrm{s}$, dla której najwyższą średnią zawartość tlenku węgla(II) w spalinach odnotowano dla temperatury $17^{\circ} \mathrm{C}$. Przy tej prędkości zarówno obniżenie temperatury napływającego powietrza do $11^{\circ} \mathrm{C}$, jak i podwyższenie do $25^{\circ} \mathrm{C}$ powodowało zmniejszenie zawartości tlenku węgla(II) w spalinach. Biorąc pod uwagę brak wyraźnej korelacji pomiędzy temperaturą napływającego powietrza a zawartością tlenku węgla(II) w spalinach oraz fakt, że średnie zawartości tego związku uzyskane dla wszystkich analizowanych prędkości napływu powietrza są mało zróżnicowane i mieszczą się w zakresie od 2496 ppm (dla temperatury $25^{\circ} \mathrm{C}$ ) do $3876 \mathrm{ppm}$ (dla temperatury $17^{\circ} \mathrm{C}$ ), można zdaniem autora stwierdzić, że temperatura napływającego powietrza ma niewielki wpływ na jakość procesu spalania zachodzącego na pojedynczym elemencie palnika inżektorowego. Analizując otrzymane wyniki zawartości tlenku węgla(II) w spalinach, należy zwrócić również uwagę na fakt, że średnie zawartości jego w spalinach odnotowane dla każdej z serii pomiarowych przekraczają kilkukrotnie $117 \mathrm{mg} / \mathrm{m}^{3}$ (około 100 ppm), a wartość ta stanowi NDSCh [3].

\section{Wnioski}

Otrzymane wyniki badań pozwalają stwierdzić, że większy wpływ na proces spalania ma prędkość napływającego powietrza niż jego temperatura. Zależność ta nie jest jednak liniowa. Można natomiast założyć, że dla pojedynczego elementu palnika inżektorowego istnieje taka prędkość napływu powietrza, przy której zawartość tlenku węgla(II) w spalinach będzie znacznie wyższa niż w przypadku innych prędkości. Dla badanego elementu prędkość ta wynosiła $0,6 \mathrm{~m} / \mathrm{s}$.

Uzyskane wyniki pomiarowe świadczą o niewielkim wpływie temperatury na jakość spalania gazu na elemencie palnika inżektorowego, jednak nie pozwalają wnioskować o kierunku zachodzących zmian oraz ich wielkości. Jednocześnie przedstawione rezultaty umożliwiają stwierdzenie, że na ja- kość zachodzącego procesu spalania istotniejszy wpływ niż temperatura powietrza mają inne parametry, takie jak np. prędkość napływu powietrza.

Przeprowadzony eksperyment pozwala wysunąć tezę, że dla każdego urządzenia typu $\mathrm{B}_{11}$ zmniejszanie prędkości napływu powietrza aż od wartości, w której zapłon jest niemożliwy, powoduje stopniowe pogarszanie jakości spalania - aż do uzyskania punktu przegięcia, w którym zawartości tlenku węgla(II) w spalinach w obu strefach są najwyższe. Dalsze obniżanie prędkości napływu powietrza powoduje zanik obecności spalin poniżej poziomu palnika, a tym samym poprawia jakość spalania. Zdaniem autora prędkość ta powinna być stała dla danego urządzenia, niezależnie od temperatury powietrza napływającego na palnik, lub wpływ tej 
temperatury będzie nieznaczny. Postawiona teza i przeprowadzone badania pokazują, jak niebezpiecznym zjawiskiem jest ciąg wsteczny, gdyż maksymalne wartości stężenia tlenku węgla(II) uzyskano przy niewielkich prędkościach napływu powietrza, które nie doprowadzają do wyłączenia urzą- dzenia. Wartości napływu powietrza, dla których otrzymano najwyższe zawartości tlenku węgla(II) w spalinach, pozwalają urządzeniu pracować w sposób normalny, bez objawów, które mogłyby wskazywać na możliwość powstania sytuacji zagrażającej zdrowiu użytkownika.

Prosimy cytować jako: Nafta-Gaz 2017, nr 8, s. 591-596, DOI: 10.18668/NG.2017.08.06

Artykuł nadesłano do Redakcji 14.12.2016 r. Zatwierdzono do druku 17.05.2017 r.

Artykuł powstał na podstawie pracy statutowej pt.: Wptyw temperatury ciagu wstecznego na działanie urzadzeń gazowych typu B - praca INiG - PIB na zlecenie MNiSW; nr zlecenia: 0091/GU/16, nr archiwalny: DK-4100-91/16.

\section{Literatura}

[1] 22 zatrucia czadem - apelujemy o ostrożność. Serwis Ministerstwa Spraw Wewnętrznych i Administracji, 8.01.2016, https://mswia.gov.pl/pl/aktualnosci/14054,22-ofiary-zatruciaczadem-apelujemy-o-ostroznosc.html (dostęp: 8.02.2016).

[2] Basiura M.: Próba wykorzystania metod rozpoznawania obrazów do oceny jakości spalania gazu. Nafta-Gaz 2015, nr 5, s. 314-319.

[3] CIOP - PIB: Karta charakterystyki substancji niebezpiecznej tlenek węgla CO; 0032 31-05-07.

[4] Czadw liczbach (Wielkopolska). Strona internetowa Komendy Wojewódzkiej Państwowej Straży Pożarnej w Poznaniu, http://www.psp.wlkp.pl/?art=915 (dostęp: 11.02.2016).

[5] MSW ostrzega przed zatruciami tlenkiem wegla. Serwis Ministerstwa Spraw Wewnętrznych i Administracji, 27.10.2014, https://mswia.gov.pl/pl/aktualnosci/12494,MSW-ostrzegaprzed-zatruciami-tlenkiem-wegla.html (dostęp: 11.02.2016).

[6] Rataj M.: Bezpieczeństwo użytkowania gazowych urządzeń grzewczych z otwarta komora spalania. Nafta-Gaz 2013, nr 6, s. 455-462.

[7] Rataj M.: Ocena wpływu ciagu wstecznego na działanie palnika inżektorowego. Nafta-Gaz 2015, nr 5, s. 320-326.

[8] Rataj M.: Wplyw warunków atmosferycznych na powstawanie ciagu wstecznego oraz możliwości jego wyeliminowania. Materiały VI Konferencji Naukowo-Technicznej Energetyka Gazowa 2016 pod red. Barteli Ł., Kaliny J., Kotowicza J., Skorka J. Wydawnictwo Instytutu Techniki Cieplnej Gliwice 2016, t. 2, s. 449-456.

[9] Tałach Z.A. Czerski G., Strugała A.: Zagrożenia zatruciem tlenkiem wegla $w$ budownictwie mieszkaniowym - techniczne możliwości poprawy bezpieczeństwa mieszkańców. Nafta-Gaz 2007, nr 1, s. 43-50.
[10] Tlenek wegla - podsumowanie sezonu grzewczego 2015/2016. Strona internetowa Komendy Głównej Państwowej Straży Pożarnej, 1.04.2016, http://www.straz.gov.pl/aktualnosci/lista_aktualnosci/idn:35885 (dostęp: 2.08.2016).

[11] Żurański J.A.: Śmiertelne zatrucia tlenkiem węgla $w$ mieszkaniach z paleniskami gazowymi. III Ogólnopolskie Sympozjum „Wpływ środowiska na budowle i ludzi - obciążenia, oddziaływania, interakcje, dyskomfort", Zwierzyniec 14-16.05.2001.

[12] Żurański J.A.: Wentylacja naturalna mieszkań z paleniskami gazowymi a śmiertelne zatrucia tlenkiem węgla. Materiały Budowlane 2012, nr 12, s. 33-34.

[13] Żurański J.A.: Zatrucia tlenkiem węgla w mieszkaniach z paleniskami gazowymi. Materiały Budowlane 2012, nr 12, s. 33-34.

\section{Akty prawne i normatywne}

[14] PN-EN 15502-2-2:2014-12 Gazowe kotty centralnego ogrzewania-Część 2-2: Norma szczegółowa dla urządzeń typu B1.

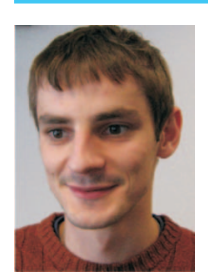

Mgr inż. Mateusz RATAJ

Asystent w Zakładzie Użytkowania Paliw. Instytut Nafty i Gazu - Państwowy Instytut Badawczy ul. Lubicz 25 A

31-503 Kraków

E-mail:mateusz.rataj@inig.pl 